\title{
Askeri Devrim ve Türk Modernleșmesine Etkisi
}

\author{
Vural BAŞARAN ${ }^{*}$ - Remzi DEMIR ${ }^{* *}$
}

\begin{abstract}
ÖZ
Avrupa'da kabaca XV. yüzyıldan XVIII. yüzyıla kadar geçen sürede askeri sahada gerçekleşen değişimleri Askeri Devrim tezleri ile açıklamaya çalışan araştırmacılar, bu dönemde gerçekleşen birtakım teknolojik, bilimsel, idari ve iktisadi gelişmeleri de söz konusu bu askeri yeniliklerle irtibatlandirmaktadırlar. Michael Roberts 1560-1660 tarihleri arasında Avrupa askeriyesinde görülen bir takım değişiklikleri Askeri Devrim olarak tanımlamıştır. Onun araştırmalarından sonra birçok tarihçi de bu konu hakkında kapsamlı araştırmalar yapmaya başlamıştır. Son yıllarda Osmanlı askeri tarihine olan ilginin giderek artması sonucunda Askeri Devrim'in hem Osmanlilara tesiri hem de Osmanlıların bu devrime katkıları ortaya konulmaya çalışılmıştır. Çalışmamızda bu araştırmalara da değinilmiştir.

Avrupalı ve Rus rakipleri ile hem coğrafi yakınlığı hem çıkar ilişkileri bulunan Osmanlıların bu askeri yeniliklerden etkilenmemesi olanaksızd1. Ĕğer Avrupa'da askeri bir devrim gerçekleşmişse Osmanlılar da bu devrimi bazı yönlerden yakalamışlardı. XVII. yüzyılın son çeyreğinden başlayarak kaybedilen savaşlar ve topraklar askeri teknik ve teknolojilerin yanı sıra Askeri Devrim'in irtibatlı olduğu bilimsel-teknolojik, idari, iktisadi ve kurumsal yapıların da Batı'dan Osmanlılara doğru aktarılması mecburiyetini doğurmuştur. Bu gelişmeler XVIII. yüzyılın ortalarına gelindiğinde Osmanlı kültür hayatının ikili bir yapıya kavuşmasına neden olmuştur. Geleneksel eğitim kurumları olan medreselerde bilgi üretme faaliyetlerine devam eden ulema sınıfı eski gücünü kaybetmeye başlamıştır. Bunun karşısında çoğu askeri ve sivil bürokrat olan mütefenninler topluluğu güçlenmiştir. XVIII. yüzyılın
\end{abstract}

* Arş. Gör. Dr., Ankara Üniversitesi, Felsefe Bölümü, Bilim Tarihi Anabilim Dalı, Ankara/TÜRKIYYE E-posta: vbasaran@ankara.edu.tr (ORCID: 0000-0002-2721-5234),DOI:

* Prof. Dr., Ankara Üniversitesi, Felsefe Bölümü, Bilim Tarihi Anabilim Dalı, Ankara/TÜRKIYE E-posta: rdemir@ankara.edu.tr (ORCID: 0000-0002-5741-7099),DOI: 10.32704/erdem.656935 Makale Gönderim Tarihi: 14.08.2019* Makale Kabul Tarihi: 25.11.2019* (Araştırma Makalesi) 
son çeyreğinde bu yeni grubun üyeleri Avrupalı tarzda eğitim veren askeri okullar kurmaya başlamıştır. Daha sonra bunları sivil okullar takip etmiştir. Bu kurumlarda Avrupa'da gelişmekte olan yeni bilimler ve sanatlar okutulmaya başlanmıştır. Balistik, iktisat, mülkiye, inşaat, gemi yapımı ve matematik gibi disiplinler bu okullarda okutulan başlıca dersler olmuştur. Yukarıda verdiğimiz gelişmeler sonucunda Osmanl1-Türk modernleşmesinin temelleri inşa edilmiştir. Yeni bilimler ve teknoloji ile beraber askeri kurumlar da Askeri Devrim’in doğal bir sonucu olarak XVIII. yüzyıl sonlarında Osmanlı mütefenninlerini diğer bilginler karşısında ayrıcalıklı bir konuma getirmiş, hatta bu bilginler diğer epistemik toplulukları yavaşça yönetimden uzaklaştırarak XX. yüzyılda tarih sahnesinden dışarı itmişlerdir.

Anahtar Kelimeler: Askeri devrim, Türk modernleşmesi, askeri okullar, Michael Roberts, Benjamin Robins. 


\title{
Military Revolution and Its Effect on Turkish Modernization
}

\begin{abstract}
Some researchers tried to explain the changes that occur in military developments approximately from the 15 th century to the 18 th century with Military Revolution thesis. They linked some of the developments in technology, administration, science and economy to the military developments. Michael Roberts described a number of changes in the European military affairs between 1560 and 1660 as the Military Revolution. After his research, many historians began to do extensive research on this subject. As a result of the increasing interest in Ottoman military history in recent years, the effect of the Military Revolution on the Ottomans and the contributions of the Ottomans to this revolution were tried to be put forward.
\end{abstract}

Ottomans were affected by these military developments because they had both geographical connection and mutual interest relationships with its European and Russian rivals. If a military revolution took place in Europe, the Ottomans tracked it down in some ways. The Ottomans started to lose wars and territories in the last quarter of the 17th century. As a result of these developments, Ottomans had to transfer the military technologies and tactics along with scientific, administrative, economic and institutional structures from Europeans. These developments caused the Ottoman cultural life to have a dual structure in the middle of the 18th century. The ulema class, which continues to produce knowledge in the madrasas, traditional educational institutions, has started to lose its previous power. On the other hand the new scientist group called mütefennin started to gain strenght. They were mostly military and civilian bureaucrats. In the last quarter of the 18th century, members of this new group began to establish European-style military schools. Then they were followed by civilian schools. New sciences and arts developing in Europe have started to be used here. Disciplines such as ballistics, economics, management, civil engineering, ship building and mathematics have been the main subjects taught in these schools to come. This led to the construction of the foundations of Ottoman-Turkish modernization. As a natural consequence of the Military Revolution, Ottoman epistemic group named "mütefennin" introduced the new sciences and the technologies to Ottomans and they founded the new military and civil institutions. The Ottoman "mütefennins" started to get the privileged position over other scholars like ulema in the late 18th century and pushed other epistemic communities out of the stage of history in the 20th century.

Keywords: Military revolution, Türkish modernization, military institutions, Michael Roberts, Benjamin Robins. 


\section{1- Avrupa'da Askeri Devrim}

on 60 yıldır bazı Batılı tarihçiler, Avrupalıların dünyanın geri kalanı üzerinde kurdukları tahakkümün nedenini Avrupa'da Erken Modern Dönem'de askerlik mesleğinde ve askeri teknolojilerde yaptıkları yeniliklerde aramak gerektiğini ifade etmektedirler. Bu değişim ve dönüşümler "Askeri Devrim" olarak adlandırılmaktadır. Tedrici/evrimsel ilerlemeyi kabul edenler de sıçramalarla/devrimci ilerlemeyi savunanlar gibi bu kavramı kullanmışlardır. Askeri Devrim kavramını ilk kez ortaya koyan Michael Roberts'tir (1908-1996) (Kingra 1993: 431). 1955 y1linda Belfast Queen Üniversitesi'nde yaptı̆̆ı açı̧ konuşmasında bu kavramı öneren Roberts’in ardından Geoffrey Parker, bu tezi hem zamansal olarak genişletmiş hem de tezin merkezini değiştirmiştir (1976). Bu konu hakkında yapılan araştırmalar bu iki ismin çalı̧̧malarının tenkit ve tebdil edilmesiyle günümüze kadar gelmiştir. Clifford Roges (1993) ve John A. Lynn (1996) gibi araştırmacılar da bu içerikte eserlere imza atmışlardır. Bu tezlerin argümanlarına kısaca değineceğiz.

Roberts, 1560-1660 yılları arasında askeri sahada gerçekleşen bir dizi değişimi ve bunlardan kaynaklanan gelişmeleri Askeri Devrim tezinin merkezine koymuştur. Buna göre, ilk devrimci dönüşüm taktik alanında yaşanmıştır. Hollandalı Maurits van Oranje (1567-1625) ile İsveçli Gustav II Adolf (1594-1632), İspanyolların tercio adını verdikleri kare düzenden üçerli sıra hâlinde dizilen lineer formasyona geçerek savaş taktiğinde önemli bir değişiklik yapmışlardır (Roberts 1995: 13-14). Taktikte gerçekleşen bu değişimin ilk sonuçlarından birisi talimli orduya olan ihtiyacın artması olmuştur. Eğitimi gerçekleştiren subaylar sadece askeri bir lider olmaktan çıkmış aynı zamanda birer eğitmen haline gelmişlerdir (Roberts 1995: 14-15). İkinci büyük değişim askere almada gerçekleşmiştir. Artık ordular paralı askeri birliklerden değil askere alınan köylülerden teşekkül etmeye başlamıştır (Roberts 1995: 16). Daha sonra bu daimi ordular, ulusal orduların ilk nüvelerini oluşturmuştur. Askeri alandaki bu gelişmeler, finans sahasında da değişikliğe gidilme ihtiyacını doğurmuştur. Daha büyük ordu ve donanmalar, daha fazla üniforma masrafi ve talim sürelerinin uzunluğunun getirdiği yük, merkezi yönetimleri finansman sorunuyla baş başa bırakmıştır. Bu sorunu aşabilmek için gelişmiş finans ve kredi sistemleri kurulmaya başlanmıştır (Roberts 1995: 22). Son olarak da bu gelişmeler, savaşı bir grup elitin elinden alıp kitlelerin bir geçim kaynağı haline getirmiştir. Elitleri temsil eden atlı şövalye ile halktan oluşan piyade arasındaki uçurum da kapanmıştır (Roberts 1995: 23). 
Roberts'in Askeri Devrim tezini 1500-1800 yılları arasına kadar genişleten Parker, çalışmasının merkezine adına trace italienne denilen yeni tarz istihkâmları koymuştur. Eski tarz kale duvarları uzun ve askerlerin üzerine çıkmasına engel olacak şekilde tasarlanmıştı. Parker'a göre topun savaş sahnesine çıkması ile birlikte bu kaleler etkisini yitirmiş ve bunun akabinde daha kısa ve kalın duvarlardan oluşan yıldız tabyalar ortaya çıkmı̧̧ır (1976: 15). Ona göre istihkâmda görülen bu değişim kara savaşlarında da bir devrimi beraberinde getirmiştir. Parker, bu iki devrimin de Rönesans İtalyası'nda ortaya çıtığını söylemiştir (1976: 22). Bu gelişmeler savaşların süresini uzatmış ve askeri maliyetleri artırmıştır. Parker’a göre askeri devrimin diğer bir önemli ayağı, savaşlarda kritik bir değişiklik yapılmasına sebep olan yaylım ateşinin geliştirilmesidir. Tüfek doldurma sürelerinin uzunluğu savaşlarda tüfekli piyadeyi etkisiz kilıyordu. Parker'ın, Hollandalıların bulduğunu ve savaşta uyguladığını iddia ettiği yay$\operatorname{lım}$ ateşi (volley fire), saflar halindeki askerlerin birbirlerinin ardı sıra ateş etme prensibine dayaniyordu. Bu da piyadelerin kare biçiminde değil de lineer formasyonda bulunmasını zorunlu k1lyordu. Bunun sonucu olarak savaşlar geniş bir bölgeye yayılmaya başladı ve 11 subayın idare ve sevk ettiği 250 kişilik ordular yerine 12 subayın eşlik ettiği 120 kişilik birlikler oluşturuldu. 2000 kişilik alayların yerine 580 kişilik tabyalar getirildi (Parker 2006: 26-27). Bu iki tez daha sonraları Jeremy Black (1995), Clifford Rogers (1993) ve John Lynn (1996) gibi tarihçiler tarafından geliştirildi. Bazı ilaveler ve eleştirilerle beraber Askeri Devrim tezleri araştırmacıların ilgisini çekmeye devam etti.

Askeri sahada görülen söz konusu bu değişikliklerin hiç şüphesiz Avrupa bilimine, teknolojisine ve iktisadına büyük etkileri olmuştur. Her şeyden önce merkezi hükümetler yeni bir finans sistemine ihtiyaç duymuş, savaş kitlelerin işi haline gelmiş, askeri nizamın sağlanması için talimli ve daimi askerlere olan ihtiyaç artmıştır. Askeri bürokrasi güçlenmiş ve Avrupa'da etkin hale gelmiştir. Bunların Avrupa ile sürekli mücadele halinde olan Osmanlılara da derin tesiri olmuştur.

\section{2- Osmanlilar ve Askeri Devrim}

Rhoads Murphey ve Gabor Agoston gibi Batılı tarihçilerin Osmanlı askeri tarihine ilgi göstermesinden sonra bu alana olan alâka artmış ve Askeri Devrim ile Osmanlılar arasındaki irtibat tartı̧̧ılmaya başlanmıştır.

Osmanlılar Bizans'a komşu küçük bir beylikten İstanbul'u ve Doğu Avrupa'yı, İran ve Mısır'ı fethedebilecek büyük bir imparatorluk olana kadar bazı deği- 
şikliklerle askeri gücünü korumayı başarabilmiştir. Bu sayede Osmanlı Hanedanlığ büyük topraklar üzerinde hâkimiyet kurmuştur. Ancak bu durum, XVII. yüzyılla beraber değişmeye başlamış, Osmanlılar Avrupalı ve Rus hasımları ile girdikleri askeri mücadelelerde geride kalmaya başlamıştır. Bu yüzy1lın sonunda ise Osmanlılar, hasımlarının meydana getirdiği Kutsal İttifak üyeleri ile imzaladığı Karlofça Anlaşması (1699) ile birlikte Batı'da ilk kez geniş çapta toprak kaybetmiştir.

Osmanlıların Askeri Devrimi yakalayıp yakalayamadığı hâlâ tartışmalı bir konu olsa da son dönemde yapılan çalı̧̧malara istinaden askeri devrimin bazı yönlerden yakalandığı ifade edilebilir. Çalışmalarını Osmanlı askeri tarihi üzerine yoğunlaştıran Gabor Ágoston, bunu şu şekilde ifade etmektedir:

Tarihçiler uzun zamandır Avrupa silahları ve taktiklerinin -görünürde 16. yüzyılın başlarından itibaren- Osmanlı muadillerine sağladığı sözde üstünlüğe ve bunun neticesinde 18. yüzyılın sonlarında gelip sultanın ordusunun Avrupai bir tarza büründüren Osmanlı askeri ıslahatlarına odaklanıyorlar. Yakın tarihli araştırmalar ise 17. yüzyıl sonlarına dek Avrupa askeri kurumlarını Osmanllarınkine daha baskın kılacak herhangi bir teknolojik, taktik ve örgütsel üstünlük olmadığı görüşünü savunmaktadırlar. Kavrayış ve uyarlayış kabiliyetleri sayesinde Osmanlılar ateşli silah teknolojisini askeri bünyelerine kolayca ve hızlıca tatbik ettikleri gibi ordularının, donanmalarının, kalelerinin ve ince donanmalarının silah, mühimmat ve levazım ihtiyaçlarını karşılamaya yetkin yerli üretim olanaklarını da kurdular. Askeri azametlerine uygun düşen idari, mali ve lojistik becerileriyle Osmanlılar, 15. yüzyılın sonlarında civar komşularına askeri üstünlüklerini kabul ettirdiler ve bu avantajlarını 17. yüzyılın sonuna dek bir dizi rakibe karşı sürdürdüler" (2017: 82).

Rhoads Murphey de Osmanlıların hiç değilse istihkâm ve lağımcılık gibi bazı alanlarda XVII. yüzyıla kadar standartları belirlediklerini ifade etmiştir (2007: 37). Hatta Parker'in askeri devrim tezinin önemli bileşenlerinden birisi olan yaylım ateşini Hollandalılardan daha önce Osmanlıların kullandığı Topşular Kâtibi Abdülkadir Efendi Taribi adlı eserdeki betimlemeden de anlaşılmaktadır (Börekçi, 2006).

Parker'ın askeri devrim tezinin merkezinde yeni tarz kaleler olduğunu yukarıda zikretmiştik. Veysel Göger, XVI. yüzyıl boyunca Osmanlıların yaptığı savaşlar üzerinden Parker'ın iddia ettiği gibi yeni tarz istihkâmların savaşların süresini anlamlı bir biçimde değiştirmediğini göstermiş ve onun tezini tartışmaya açan bir çalışma yapmıştır (2017). 
Özgür Kolçak ise 1660-1664 tarihleri arasında Osmanlılar ile Avusturya arasında gerçekleşen savaşı incelediği araştırmasında "Öyle ki, 16-17. yüzyıllarda bir askerî devrim yaşandıysa bile, ya bu devrim henüz meyve verecek olgunluğa ulaşmamıştı; ya da, derece farklılıklarını gözetmek kaydıyla, Osmanlı askerî yapısı da bu gelişim çizgisinin bir parçasıydı" (2012: 384) sonucuna ulaşmıştır. Yukarıda kısaca değindiğimiz araştırmalar ve yazarlarının ulaştıkları veriler, bize Askeri Devrim'in Osmanlılar tarafından takip edildiğinin işaretlerini sunmaktadır.

\section{Askeri Devrimin Bazı Sonuçlanı}

Askeri sahadaki gelişmelerin kültürel ve iktisadi pek çok sonucu olmuştur. Askeri Devrim'in doğrudan tesirinin olduğu alanlardan ilki iktisat ve finansmandır. Ekonomi politiğin kurucusu Adam Smith (1723-1790) 1776 yllında kaleme aldığı ve artık bir iktisat klasiği haline gelmiş olan Milletlerin Zenginliğ $i$ adlı eserinin "Savunma Masrafları" başlıklı bölümünde, ateşli silahların ve askeriyenin gelişmesi ile ortaya çıkan finansman problemini ele almıştır. Ona göre “...askeri kuvvetin hem barış zamanında hazırlanmasına, hem savaş sırasinda kullanılmasına müteallik masraf, topluluğun türlü durumlarında, türlü ilerleme devirlerinde başka başkadır” (Smith 1995: 334). ${ }^{1}$

Smith kavimleri dört devirde tanımlamıştır. İlki Kuzey Amerika yerlilerinde örneklerine rastlanılan avcı kavimlerdir ki bunlar hâlihazırda hem avcı hem de savaşçıdır. Bu toplulukta hükümdar ya da devlet gibi bir mekanizma yoktur ve savaş toplum üzerinde herhangi bir fazladan masrafa sebep olmaz (Smith 1995: 334-335). İkinci bir kavim türü olan ve Tatarlar ile Araplarda görülen, avcılardan daha ileri bir topluluğu temsil eden çoban kavimlerde de her adam aynı zamanda bir savaş̧̧ıdır. Bu kavimlerin yaşam tarzı savaşta ve barışta değişmez (Smith 1995: 337). Topluluk daha ileri bir durumunda ise diş ticaretin sınırlı olduğu ziraatçi kavimler vardır. Burada da her adam ya savaşçıdır ya da savaşa çok hızlı bir şekilde hazırlanabilir. Bu gibi gruplarda savaşa hazırlanma ve askere alma hükümdara nadiren herhangi bir masrafa mâl olur (Smith 1995: 338). Topluluk daha ileri bir durumunda ise iki sebep askerlerin bakımı ve iaşesi için hükümdara veya devlete masrafı artırmıştır. Bunlardan ilki sanayiinin gelişmesidir. Diğeri ise savaş sanatlarındaki gelişmedir (Smith 1995: 340). Bir çiftçi tohumunu ektikten sonra savaşa gidebilir. Geri kalan işi tabiat kuvvetleri yapacaktır. Ancak bir demirci, marangoz yahut dokumacı imalathanesinin

1 Mali yapı ve savaşın buna etkisine dair ayrıca bkz: (Gökbunar, Gökbunar, \& Uğur 2010) 
başından ayrılır ayrılmaz biricik geliri kuruyuverir. Bu yüzden onun ihtiyaçları devletçe karşılanmalıdır (Smith 1995: 341). İlaveten Smith'e göre savaş sanatlarındaki hâl giderek karmaşık bir şekle bürünmüştür. Savaşlar mevsimin bazı dönemlerinde göğüs göğüse mücadele etmekten daha çok yllın bütününe yayılan bir hâle gelmiştir (Smith 1995: 344). Ayrıca ateşli silahların maliyetlerinin yükselmesi bu masraflara katlanmaya gücü yeten milletler lehine savaşların sonuçlarını değiştirmiştir (Smith 1995: 364).

Askeri devrim sadece iktisadî sahada değişikliklere yol açmamıştır. Bununla beraber teknik ve bilimsel düşüncede de önemli ihtiyaçları ortaya çıkarmıştır. Bu ihtiyaçları iki kısımda inceleyebiliriz: 1) bilimsel alanda ve 2) teknolojik ya da mühendislik alanında.

Askeri Devrim'in bilimsel alanda doğurduğu ihtiyaçların en önemlilerinden birinin balistik olduğunu söyleyebiliriz. İç ve dış balistik olarak ikiye ayrılan bu dalın gelişimi fiziğin, mekanik ve termodinamik gibi çok önemli alanlarının gelişiminde önemli bir itki oluşturmuştur. Bunlardan dış balistik, mermi ya da güllenin gideceği mesafeyi ve yörüngesini izleyip betimlemeye yarayan bilim dalıdır. Bu alanda ilk matematiksel çalı̧̧maları yapan ve teorik topçuluğun kurucusu olan İtalyan bilgin Niccolo Tartaglia'dır (Hall 2009: 33). Tartaglia (1499-1557), 1537 yılında yazdığı Nova Scientia adlı eserde firlatılan bir güllenin en uzak mesafeye gitmesi için topun yerle yaptığı açının 45 derece olması gerektiğini göstermiştir (Cuomo 1997: 161-163). Ayrıca dereceli kadranı topların eğimlerini hesap etmek için ilk kullanan da kendisi olmuştur.

Bilimsel Devrim'in en önemli figürlerinden birisi olan İtalyan bilgin Galileo Galilei (1564-1642), İki Yeni Bilim Üzerine Diyaloglar ve Matematiksel Kanıtlamalar (1638) adıyla kaleme aldığı eserinin ilk gün diyaloglarına şöyle bir giriş yapmıştır: "Siz Venediklilerin meşhur tophanenizde yapageldiğiniz deneyler hevesli zihinlere özellikle mekanik alanının konularına giren geniş bir araştırma alanı sunuyor; çünkü devamlı olarak üretilen alet ve makineleri yapan zanaatkârlar arasında kısmen de kendi gözlemleriyle çok zekice açıklamalar yapabilen kimseler de olmalı." (Galilei 1914: 1). Bu girişe uygun bir biçimde de kitabının sonuna balistik cetveli koymuştur (Galilei 1914: 287). Topçuluğun ve ateşli silahların mekaniğin gelişmesinde oynadığ̣ rolü göstermesi açısından Galileo ve Tartaglia iyi birer örnektir.

Galileo, araştırmalarını hava sürtünmesinin yarattığı etkiyi göz ardı ederek yapmıştır. Hava sürtünmesinden kaynaklanan etkinin çok büyük olduğunu 
bilmesine karşın bunları hesap edecek matematiksel ve teknolojik aygıtlardan yoksun olması kendini bu yola sevk etmiş̧ir. Hava sürtünmesini hesaba katarak atış problemlerine matematiksel çözümler bulma çabasına giren ilk bilim insanları ise İsveçli matematikçi Johann Bernoulli (1667-1748), Hollanda11 bilgin Christiaan Huygens (1629-1695) ve bilim devriminin belki de en önemli figürü Isaac Newton'dur (1643-1727). Bu yazarlar her ne kadar hava sürtünmesinin oluşturduğu direnci hızın karesiyle orantılı olarak vermişse de bu varsayım doğru değildi. Söz konusu bu problemi çözmedeki en büyük zorluk lineer olmayan diferansiyel denklemlerin ortaya çıkardığı matematiksel engeldi. Başlangıç koşullarının bilinmemesi bu denklemlerin çözümünü olanaksız kılıyordu. Problemin çözümü, deneyci bilim tarzlarıyla ünlenmiş olan İngiltere'de hem mühendislik hem de bilim alanında çok önemli işler yapmış olan Benjamin Robins'ten geldi (1707-1751). Balistik sarkacını bulması ateşli silahlara dair birçok sorunun çözülmesine olanak sağladı. Bu sarkaç sayesinde bilim insanları topun namlu ağzından çıkış hızını hesaplama yeteneğine erişmişlerdir. Robins'in balistik sarkacından elde edilen veriler Leonhard Euler tarafindan sürtünmeli ortamlardaki atış problemlerine uygulanmıştır. Böylelikle XVIII. yüzyılın ortalarına gelindiğinde askeri ihtiyaçları gidermek için balistik biliminde deney ve teori bir araya getirilmiştir.

Kimya alanında Bilimsel Devrim’in en önemli figürlerinden birisi olan hatta kendisine sıklıkla modern kimyanın kurucusu payesi verilen Antoine Lavoisier (1743-1794), dâhili balistik alanına giren ve topçuluk için çok önemli olan barut araştırmalarında önemli roller üstlenmiştir. Régie des Poudres et Salpêtres (Barut ve Güherçile Yönetimi) adlı kurumda yöneticilik görevine getirilmiş ve burada yaptığ çalışmalarla daha verimli barut yapımına katkıda bulunmuştur. Bu kurumda çalışan bir diğer kimyacı Claude-louis Berthollet uçucu potasyum klorür kullanarak çok daha güçlü bir barut keşfetmiştir. Tophane Lavoisier'nin çalışma hayatının merkezinde yer almıştır (Bell 2005: 21-27).

Diğer bir değişim pek tabiidir ki teknolojide ortaya çıkmıştır. XV. yüzyılda ağır topçuluğun gösterdiği muazzam gelişme ile beraber metallere duyulan ihtiyaç artmıştır. Madenlerin derinliği cevherleri yeryüzüne çıkarmak için pek çok güçlük ortaya çıkarıyordu. Madendeki suyu dişarı çıkarmak, madenleri havalandırmak ve cevherleri yukarıya çıkarmak için pek çok alet ve edevata ihtiyaç duyulmaktaydı. Bu problemleri çözebilmek için pompalar, yük asansörleri, havalandırma boruları ve hava üfleme motorları inşa edildi 
(Hessen 2010: 75). Askeri Devrim'in ve Endüstri Devrimi'nin ortak ihtiyaçlarının giderilmesi için teknolojik aletler daha iyi ve verimli hale getirilmeye çalışılmıştır.

İstihkâm alanındaki gelişme ile beraber inşaat faaliyetleri de gelişme göstermiştir. Parker'ın Askeri Devrim’in önemli bileşenlerinden birisinin istihkâm alanında yaşanan gelişmeler olduğunu ifade etmiştik. İstihkâm teknolojisine en önemli katkı, Fransız askeri mimar/mühendis Marquis de Vauban (16331707) tarafından yapılmıştır. XIV. Louis’in kale mühendisliğini de yapan Vauban, Parker'ın işaret ettiği tarzda pek çok kale yapmı̧̧ ve eserler kaleme almı̧̧ıิr.

Askeri gelişimin diğer bir önemli sonucu, eğitimli subay ve astsubaya olan ihtiyacın artmasıdır. Nassau Kontu John 1617-23 y1lları arasında Siegen'de kendisinin idare ettiği bir schola militaris yani askeri akademi kurmuştu. Buranın asıl amacı teknik yetenekleri geliştirilmiş piyade sınıfı subaylar yetiştirmekti. Yine bu yüzyılda, Fransa ve Almanya'da beş askeri akademinin kurulduğu tespit edilmiştir. Romalılar dönemindeki gibi savaşta liderlik vasfını yürüten askerlerin sivil yönünün de ağır basması gerekliliği ortaya çıkmıştır. Özellikle topçu ve istihkâm sınıfina mensup subayların matematik ve geometri bilmesi zorunlu bir hale gelmişti. Artık avcılık, şahincilik ve at üstünde mızrak dövüşü gibi oyunların bir savaşçının yetişmesi için yeterli olduğu düşüncesinin sonuna gelinmiştir (Keegan 2019: 446-447).

\section{3- Osmanlılarda Modernleşme Çabaları ve Yeni Epistemik Cemaat}

Osmanlı askeri sistemi tarihsel olarak iki bileşenden oluşmaktadır. Bunlar 1) Merkez ve 2) Taşra teşkilatlarıdır. Merkez teşkilatı dediğimiz ve maaşlı çalışan askerlerin yaya kısmını yeniçeriler, cebeciler, topçular ve top arabacıları oluştururken taşra teşkilatını tımarlı sipahiler ve akıncılar vücuda getirmiştir (Uzunçarşılı 1988: 2). Askeri devrimin sonuçlarından birisi olan merkezi ordudaki askerlerin sayıca çoğalması ve talimli asker ihtiyacının artması, mühendislik ihtiyaçlarının karşılanması gibi birtakım problemler Osmanlı düşünürleri ve yönetim kadrosunun ilgi alanına XVIII. yüzyılda girmeye başlamış görünmektedir.

Öncelikle Humbaracı Ahmet Paşa'nın (1675-1747) gayretleri ile eski gücünden yoksun olan humbara ocağı tekrar güçlendirilmeye başlanmıştır (Uzunçarş1lı 1988: 118-120). Ahmet Paşa'nın ölümünden sonra bu ocağın çalışmaları 
sekteye uğrasa da daha sonra Gazi Hasan Paşa’nın (1713-1790) girişimleri ile birlikte Tersane-i Âmire içinde askeri-mühendislik eğitimi verilebilmesi için 1775 yılında Mühendishâne-i Bahrî-i Hümayûn açılmıştır. Burada başta Baron de Tott olmak üzere Fransız uzmanların ders vermesi istenmiştir. 1795 y1lında ise karacı sınıflar için mühendis yetiştirecek olan Mühendishâne-i Berrî-i Hümayûn açılmıştır. Bu iki askeri mühendis okulu aynı zamanda Avrupa'da gelişen yeni bilim ve düşünceleri de Osmanlılara aktarmaya başlamıştır. Mühendishâne-i Bahrî-i Hümayûn'da 1793'te Fransız gemi inşa mühendisi Le Brun'un mütalaası ile birlikte hazırlanan ders programında ilm-i rakam, ilm-i hendese, resim ve gemi tasvirlerinin yanında bunların uygulamalarının öğretildiği bir ders programı oluşturulmuştur (Kaçar 2008: 72).

Bu yüzyılın sonunda Nizâm-1 Cedid (Yeni Düzen) olarak adlandırılacak birtakım reform çalışmaları yapılmıştır. 1789 yılında tahta çıkan III. Selim’in saltanatı süresince ülke sathındaki bozulmayı önlemek için reformlar yapma fikri ağır basmıştır. Islahat fikrinin doğması ile beraber yedi alanda yenileşme ve düzenlemeye gidilmesine dair bir irade oluşmuştur. Bu alanlar şunlardır: 1) Askeri saha, 2) İdari saha, 3) İlmiye, 4) İktisadi saha, 5) Ticari saha, 6) Siyasi saha ve 7) Diplomatik saha (Karal 1988). Bunların içinde en mühim görülen askeri alanda yapılacak düzenlemelerdir. Osmanlılar ve Askeri Devrim bahsinde Devlet-i Aliye'nin askeri devrimi kısmen de olsa yakaladığı iddialarını tartışmıştık. Bu noktainazardan hareket edecek olursak XVIII. ve XIX. yüzyıllarda görülen gelişmeler, yazılan metinler, verilen layihalar incelendiğinde bunların önemli bir kısmının askeri devrimin anılan bazı sonuçları ile büyük bir paralellik gösterdiği gözlenmektedir.

Osmanlılarda evvela humbaracı sınıfının ve ocağının eğitim işinde düzenlemeye gidilmiştir. Humbaracı personeline geometri bilgisi ve atış sanatında uzman ustalardan dersler verdirilmeye başlanmıştır. Bu bağlamda XVIII. yüzyılın ortalarından başlayarak humbaracılar ve topçular için yazılmış balistik metinleri karşımıza çıkmaktadır. Bazı metinler sadece harici balistiğe hasredilmişken kimi yazarlar dâhili balistiği de içeren eserler kaleme almışlardır. Pek çoğu kâtip olan bu yazarlar, humbaraların atış prensiplerini tanıtmayı amaçlamışlardır. Mustafa İbn İbrahim (XVIII. yüzyıl), Halifezâde İsmail Çınarî Efendi (ö. 1790), İbrahim Kâmî Efendi (1807’ler), Yahya Naci Efendi (ö. 1824) ve Başhoca İshak Efendi (ö. 1836) gibi isimler ${ }^{2}$ bu alanın

2 Bu isimlerle ilgili yaptığımız çalışmalar için bkz: (Başaran, 2015, 2017). Ayrıca bkz: (İhsanoğlu, Şeşen, Bekar, \& Gündüz, 2004) 
Osmanlılardaki öncüleri olarak zikredilebilir. Burada ismi geçenlerin eserlerinin mahiyet ve içeriklerini vermeye gerek duymuyoruz. Sadece genel olarak bahsedecek olursak, Galileo fiziği, Newton mekaniği, barutun yanmasına dair dâhili balistik konuları, ondalık kesirler, trigonometri ve logaritmanın topçuluk sahasında uygulanması gibi modern kuramsal ve deneysel pek çok bilgi bu isimlerin eserlerinde mevcuttur. Fizikteki ilk sembolleştirme ve formüller yine bu isimler tarafindan Osmanlılara tanıtılmıştır. Açılan mühendishanelerde bu isimler dersler vermiş ve kitapları okutulmuştur.

Nizam-1 Cedid hareketi, 1806 yılında yeniçerilerin isyanı sonucunda sekteye uğrayıp reform hareketlerini yavaşlatsa da bütünüyle ortadan kaldırmamıştır. XIX. yüzyılda yenilikçiler çalı̧̧malarına devam etmişlerdir. Osmanlı tarihinde ilk iktisat kitaplarından birisi olan ve müellifi belli olmayan ancak Avrupalı kaynaklardan yararlanılarak yazıldığı tespit edilen Risâle-i Tedbîr-i 'Umrân-ı Mülkî adlı eser, hem iktisadi problemin kaynă̆ını tahlil etmesi açısından hem de öneriler bakımından mühim bir kitap olarak karşımıza çıkmaktadır.

1830'larda yazıldığı (Kılınçoğlu 2018: 9) tahmin edilen eserde ilgili bölümde yeni askeri teknolojilerin ve sistemin etkileri anlatılmaktadir: ${ }^{3}$

Eyyâm-1 maziyyede vücûdu nâ-bûd ve düvel-i sâlife zamânlarında eser ü haberi ma'dûm ü mefkûd olan eczâ-i bârût zuhûr ü hudûs idüp ânın muktezâsından olan esliha-i nâriyyenin karîn-i îcâd ve hurûb ü kitâlde isti'mâli mu'tâd olduktan sonra usûl-i muhârebe ve ândan matlûb olan zafer ü galebe esbâbı tağyir ü tebdil olunmağla düvel ü milel-i müteahhirenin sâir nizâmât-1 dâhiliyye-i mülkiyyelerinin tebdîlini îcâb ve ale'l-husûs 'umrân-1 mülkîye 'âid nizâm ü tedbirin 'ilm-i mazbut nisâbına iblâğ ü isâlini istîcâb itmiş olduğu beyânında risâle-i muhtasaradır (Kılınçoğlu 2018: 81).

Kezâlik edvâr-1 sâlifede 'asâkir-i gayr-1 müte'allimenin isti'mâl iylediği âlât-1 kadîme-i harb ü kıtâlin hüsûl-i tedâriki bayâğg kaba ve basit san'atlar ile vücûda gelmekle âhâd-1 'asker ve neferât-1 leşkerden herkes kendi silahının tedârik ü istihsâline muktedir ve o takrîb-i hazâin-i mîriyyeye mûcib masârif-i külliye olmadığı bâhir ve amma esliha-i nâriyyenin îcâdından sonra âlât-1 harb ü kitâl top ü humbara ve tüfeng ü piştov ve gülle ü bârût ü kûrşûn ve sâir ta'bîr ü takrîrden efzûn edevât-1 harbiyyeye menût ve bunların i'mâli ve kemâl ü cevdet üzere tedârik ü istihsâli hem masârif-i kesîre ve hem nice fünûn-1 ma'arif-i

3 Müellifi belli olmaya eserin Latin harfli basımları iki ayrı çalışmanın konusu olmuştur. Biz bunlardan Kilınçoğlu'nunkini tercih ettik. Diğer için bkz: (Aydar 2016) Ayrıca bkz: (Ortaylı 2004) 
'acîbe ve sanâyi-i garîbe ü mürekkebeye mütevakkıf ü meşrût olduğu emr-i zâhirdir (K1lınçoğlu 2018: 85-87).

Alıntı yaptı̆̆ımız söz konusu bu eserde, eski ordu sistemi ile yeni ordu sistemlerinin sonucunda ortaya çıan bazı iktisadi ve mali problemler ele alınmıştır. Eserin ihtiva ettiği konulara bakınca, XIX. yüzyılın ilk yarısında en azından bazı Osmanlı aydınlarının askeri durum ve iktisadi farklılaşma arasındaki ilişkiye dair bir bilince sahip olduğu anlaşılmaktadır.

Böylece Askeri Devrim’in sonucunda ortaya çıkan ihtiyaçlar, Osmanlıları aşağıdaki yenilikleri yapmaya mecbur bırakmıştır:

1) Geometri ve matematik bilgisi iyi humbaracılar yetiştirmek,

2) Askeri mühimmat ve teknolojiyi geliştirmesi için yabancı uzmanları getirmek,

3) Orduya nitelikli subay ve astsubay yetiştirmek için öncelikle mühendishaneler açmak,

4) İstihkâm alanında Vauban gibi uzmanların kitaplarını Türkçeye çevirtmek,

5) Nitelikli hekim yetiştirmek için tıp okulları açmak,

6) İktisat sahasında değişimler önermek ve gerekçelendirmek.

Yukarıda özetlediğimiz ve Askeri Devrim’in sonuçları ile doğrudan irtibat1 olan Galileocu ve Newtoncu fizik, modern kimya gibi temel doğa bilimlerinin güncel konuları Osmanlı subayları, askeri mühendisleri ve tabipleri tarafindan bilinir olmaya başlamıştır. Ayrıca yine söz konusu bu devrimin sonucunda ortaya çıkan iktisadi gereksinimlere vurgu yapılmaya başlanmıştır.

\section{4- Mütefenninler versus Âlimler}

Osmanlılarda, iki farklı epistemik grup bilgi âlemine ve bununla irtibatı bulunan yönetim sistemine egemen olmak için birbirleriyle çatışmışlardır. $\mathrm{Bu}$ gruplardan ilki Âlimler Topluluğu denen ve XVIII. yüzyıla kadar iktidarı yönlendirmeye muktedir olan ulema sınıfıdır. Müderrisler, müftüler, kadıve naiblerden oluşan bu topluluğun temel amacı İmparatorluğun tedrisî, hukukî ve beledî gereksinimini karşılamak için bilgiyi, yani 'ilm’i üretmektir. Skolastik bir yaklaşım sergileyen âlimler, Kuran, hadis, icma ve kıyastan istifade ederek yöntemlerini belirlemişlerdir. Genel olarak eğitim ve öğretim kurumu 
medreseler olan bu topluluk, Türk Devrimi'nden sonra medreselerin kapanması ile tarih sahnesinden bütünüyle çekilmiştir. ${ }^{4}$

Osmanlılarda gelişen ikinci epistemik grup ise Mütefenninler Topluluğu'dur. Bu topluluk XVIII. yüzyılda güçlenmeye başlamış, Batı'nın bilim ve teknolojisini Türkiye'ye aktarmaya ve yerleştirmeye çalışmıştır. Bu topluluğun bilgisi bilim ya da fendir ve diğer toplulukların ilminden farklı bir içeriğe sahiptir. Asker ve sivil bürokratlar, hekimler, mühendisler ve mülkiyelilerden oluşan bu grubun amac1, Osmanlı İmparatorluğu'nun çöküşünü önlemek ve Avrupa bilim ve tekniğini Doğu'ya aktarmak ve kullanmaktır. Deneysel metot temel yöntemleridir. Mühendishaneler, tıbbiye, harbiye mülkiye gibi kurumlarda yeni epistemeyi yaygınlaştırmaya çalışmışlardır (Demir 2019).

Yukarıda sözü geçen iki epistemik cemaatin bilgi türleri arasında ciddi farklar mevcuttur. Mütefenninler Osmanlı Devleti'ni kurtarma motivasyonuyla Batı'da gelişen la-dinî ya da seküler bilimi Türk toplumuna tanıtma gayretine girmişlerdir. Osmanlı iktidarı, bu görevi XVIII. yüzyılda giderek güçlenen askeri ve siyasi bürokrasiye tevdi etmek mecburiyetinde kalmıştır (Demir 2018).

$\mathrm{Bu}$ iki epistemik topluluk ve bunların siyasi iktidarla arasındaki ilişkilere baktığımızda XVIII. yüzyılın sonuna doğru mütefenninlerin diğer toplulukla dengeyi kurmaya başladığı görülmektedir. Devlet-i Aliye'nin ihtiyaçlarını karşılamak için göreve çağrılan bu grup, XX. yüzyılın ilk çeyreği bittiğinde diğer epistemik grupları artık tarih sahnesinden dışarı itmiştir. Bu çatışmanın taraftarlarından mütefenninler yukarıda serimlediğimiz biçimiyle Askeri Devrim'in doğurduğu bilimsel, teknolojik ve iktisadi sonuçların gereklerini yerine getirmişlerdir. Osmanlı bilim ve buna bağlı olarak modernleşme tarihi bu iki grup arasındaki çatı̧̧ma ekseninde incelenirse daha verimli sonuçlar elde edilebileceği kanaatindeyiz.

4 Bir topluluk olarak tasavvuf öğretisini geliştiren arifler grubu da Osmanlılarda zaman zaman etkin olmuşlardır. Şeyh ve müritlerden oluşan bu topluluk tekkelerde örgütlenerek faaliyetlerini sürdürmüşlerdir. Mistik bir yaklaşım sergilemişler, ilham veya keşfi vahiyle beraber bilginin temel kaynakları olarak görmüşlerdir.(Demir 2019) Ancak diğer iki topluluk kadar siyasete yön vermekte ve iktidar çatışmasının tarafı olmakta mahir olmadıklarından çalışmamızda bu gruba değinmeyeceğiz. 


\section{SONUÇ}

Askeri Devrim teorileri Avrupa'nın Dünya üzerindeki hegemonyasının nedenlerini anlamada araştırmacılara iyi veriler sunmaktadır. Bu devrimin bilim ve teknoloji ile iktisadi sahada derin değişiklikler yarattığı anlaşılmaktadır. Askeri Devrim'in sonucunda ortaya çıkan bazı bilimsel ve teknolojik problemlerin çözümü için gösterilen uğraş, özellikle fizik ve kimya alanlarında önemli gelişmelerin yaşanmasını sağlamıştır. Bilimsel Devrim’in en önemli ve itici güçlerinden birisi olan fizik biliminin, balistik alanında yapılan araştırmalara pek çok şey borçlu olduğu anlaşılmaktadır. Bunların da teknoloji ile olan irtibatı açıktır. Ancak yine de özellikle Avrupa'daki gelişim için modern devlet ve modern bilim fikirlerinin askeri devrimin doğrudan bir sonucu olduğunu söylemek noktasında ihtiyatlı yaklaşmak gerekmektedir. Batı'nın dinamikleri dikkate alındığında bu yorum, pek çok eleştiriye de açık hale gelmektedir.

Osmanl1-Türk modernleşmesinde ise Avrupa'da müphem bir şekilde ortaya çıkan modern devlet-askeri devrim irtibatı daha net bir biçimde görünmektedir. XVIII. yüzyılın ortalarından başlayarak askeri ve sivil bürokratlar diyebileceğimiz şahıslar arasından çıkan bazı yazarlar balistik metinleri kaleme almışlardır. Avrupalı tarzda mühendishaneler kurulmuş ve burada geometri, matematik Fransızca ve mühendislik eğitimi verilmeye başlanmıştır. XVIII. yüzyılın başlarına kadar özellikle Askeri Devrim’i belli başlı alanlarda yakalamış bulunan Osmanlılar bunun doğurduğu sonuçlar üzerine de çalı̧̧arak ve yenileşme hareketlerine girişmişlerdir. Bu yüzden Osmanl1-Türk modernleşmesi Askeri Devrim’in dolaysız bir sonucu ve ilerlemenin kilit taşı haline gelmiştir. Askeri ve sivil mütefenninler, mühendisler, hekimler ve bürokratlar epistemeleri artık iş görmeyen diğer epistemik cemaatler karşısında gücü ele geçirmişler ve modern Türkiye'nin inşasına başlamışlardır. 


\section{KAYNAKLAR}

Ágoston, Gabor (2017). Osmanlida Ateşli Silablar ve Askeri Devrim Tartı̧şaları, Çev. Kahraman Şakul, İstanbul: Türkiye İş Bankası.

Aydar, Metin (2016). Risâle-i Tedbîr-i 'Umrân-ı Mülkî: Osmanlı Devleti'nde İktisat İlmini Dair Bir Risâle (Yüksek Lisans), Gaziosmanpaşa Üniversitesi, Tokat.

Başaran, Vural (2015). “'Osmanlilar'da Balistik ve Modern Fizik İlişkisi”, Ankara Üniversitesi Dil ve Tarih-Coğrafya Fakültesi Dergisi, 55(1), s. 69-89.

(2017). Osmanlılarda XVIII. Yüzyılda Balistik Çalısmaları (Doktora Tezi), Ankara Üniversitesi, Ankara.

Bell, Madison Smart (2005). Lavoisier in the Year One: The Birth of a Nerw Science in an Age of Revolution, New York ; London: Atlas Books.

Black, Jeremy (1995). A Military revolution? A 1660-1792 Perspective, İçinde, Clifford Rogers (Ed.), The Military Revolution Debate: Readings on the Military Transformation of Early Modern Europe, s. 95-114, Oxford: Westview Press.

Börekçi, Günhan (2006). "A Contrubition to the Military Revolution Debate: The Janissaries Use of Volley Fire During The Long OttomanHabsburg War of 1593-1606 and the Problem of Origins", Acta Orientalia Academiae Scientiarum Hungaricae 59(4), s. 407-438.

Cuomo, Serafina (1997). "Shooting by the Book: Notes on Niccolo Tartaglia's Nova Scientia". History of Science 35(2), s. 155-188.

Demir, Remzi (2018). “'̇ki Ayr1 Epistemik Cemaat, İki Farklı Epistemik Ĕ̆ilim”, Bilim ve Ütopya 291. Ütopya 296, s. 60-62.

(2019). Bilginin Efendileri: Üç Epistemik Cemaat. Bilim ve

Galilei, Galileo (1914). Dialogues concerning two new sciences, Çer. H. Crew \& A. de Salvio, New York: Macmillan.

Göger, Veysel (2017). “Askerî Devrim Kuramı ve XVI. Yüzyıl Osmanlı Kale Kuşatmaları". Dîvân 22(42), s. 67-106.

Gökbunar, R., Gökbunar, A. R., \& Uğur, A. (2010). “17. Yüzy1lda Osmanlı Devleti ve Batı Avrupa Devletleri’nde Mali Yapı Üzerine Savaşın Etkileri”, Maliye Dergisi (159), s. 71-87. 
Hall, Alfred Rupert (2009). Ballistics in the Seventeenth Century, Cambridge ; New York: Cambridge University Press.

Hessen, Boris (2010). Nerwton'un Principia'sının Toplumsal ve Ekonomik Kökenleri, Bekir Balkız \& Vefa Saygın Öğütle (Ed.), Çev. Eren Buğlalılar, "Bilim Sosyolojisi İncelemeleri”, s. 65-147, Ankara: Doğu Bat1.

İhsanoğlu, E., Şeşen, R., Bekar, M. S., \& Gündüz, G. (2004). Osmanlı Askerlik Literatürü Taribi Cilt 1, İstanbul: IRCICA.

Kaçar, Mustafa (2008). "Tersâne Hendesehânesi’nden Bahriye Mektebi’ne Mühendishâne-i Bahrî-i Hümâyûn”, Osmanlı Bilimi Araştırmaları 9(1), s. 51-77.

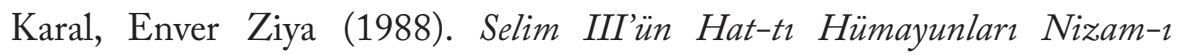
Cedit-1789-1807, Ankara: Türk Tarih Kurumu Basımevi.

Keegan, John (2019). Savaş Sanatı Taribi, Çev. Selma Koçak, İstanbul: Say.

Kingra, Mahinder S. (1993). "The Trace Italienne and the Military Revolution During the Eighty Years' War, 1567-1648”, Journal of Military History 57(3), s. 431-446.

Kılınçoğlu, Deniz T. (2018). İslâm, İktisat, Ordu ve Reform: Osmanlı İmparatorluğu’nda İlk İktisat Eseri ve Taribsel Bağlamı, İstanbul: İstanbul Bilgi Üniversitesi Yayınları.

Kolçak, Özgür (2012). XVII. Yüzyıl Askeri Gelişimi ve Osmanlılar: 16601664 Osmanlı-Avusturya Savaşları (Doktora Tezi), İstanbul Üniversitesi, İstanbul.

Lynn, John Albert (1996). "The Evolution of Army Style in the Modern West, 800-2000”. International History Review 18(3), s. 505-545. https:// doi.org/10.1080/07075332.1996.9640752

Murphey, Rhoads (2007). Osmanlida Ordu ve Savaș 1500-1700, Çev. Tanju Akad, İstanbul: Homer Kitabevi.

Ortaylı, İlber (2004). "Osmanlılarda İlk Telif İktisat Elyazması", İçinde, Osmanlı İmparatorluğu’nda İktisadi ve Sosyal Değiş̧im Makaleler-1, s. 455462, Ankara: Turhan Kitabevi.

Parker, Geoffrey (1976). “The 'Military Revolution' 1560-1660: A Myth?” The Journal Of Modern History 48(2), s. 195-214. 
(2006). Askeri Devrim: Batının Yükselişinde Askeri Yenilikler 1500-1800, Çev. Tuncay Zorlu, İstanbul: Küre Yayınları.

Roberts, Michael (1995). The Military Revolution, 1560-1660. Clifford J. Rogers (Ed.), "The Military Revolution Debate: Readings on the Military Transformation of Early Modern Europe", Boulder, Colo.; Oxford: Westview.

Rogers, Clifford J. (1993). "The Military Revolutions of the Hundred Years' War", The Journal of Military History, 57(2), 241-278.

Smith, Adam (1995). Milletlerin Zenginliği, Cilt 3; Çev. H. Derin, Ankara: Maarif Basımevi.

Uzunçarşı11, İsmail Hakkı (1988). Kapukulu Ocakları, Cilt 2, Ankara: Türk Tarih Kurumu Basımevi. 